Behavior and Social Issues, 26, 172-186 (2017). (C) Carsta Simon. Readers of this article may copy it without the copyright owner's permission, if the author and publisher are acknowledged in the copy and the copy is used for educational, not-for-profit purposes. doi: 10.5210/bsi.v.26i0.7317

\title{
Why Norwegians Don't Have Their Pigs in the Forest: ILLUMINATING NORDIC 'CO-OPERATION'
}

\author{
Carsta Simon ${ }^{1}$ \\ Oslo and Akershus University College, Norway
}

\begin{abstract}
Many situations in human life present choices between (a) alternatives beneficial to an individual and (b) alternatives that are less beneficial to the individual, but could be beneficial if chosen by many individuals. Choices of the latter alternative are generally considered cooperative. Taking the supposition that a lack of cooperation between and amongst societies lies behind many crises of the $21 \mathrm{st}$ century as its point of origin, the paper takes a two-step approach to shed light on the Nordic culturalevolutionary puzzle of managing to maintain a dynamic equilibrium between competition and cooperation. First, the paper suggests cooperation as a valuable temporally extended pattern of behavior that may be learned and maintained over an individual's lifetime. Second, the paper examines how Norwegian and Swedish culture fosters a commitment to extended patterns of cooperative behavior. By means of interpreting successful Scandinavian cultural characteristics in the light of selection of behavior both during phylogeny and during ontogeny, the paper derives hypotheses about functional relations between behavioral and environmental events that make for the success of the Nordic nations and which might inspire policy development in other countries.

KEYWORDS: cooperation, temporally extended behavioral patterns, Nordic Model, Scandinavian culture, levels of selection
\end{abstract}

Norway led the United Nations Human Development Index matrices for five consecutive years (UN, 2015). The Scandinavian countries score high on any list of life quality and economy indicators, indicating that they - compared to other nations - function exceptionally well. What makes the Scandinavian countries and in particular Norway so successful? D.S. Wilson and D.O. Hessen (2014) have suggested that the economic and social policies common to the Nordic countries, known as the Nordic Model, work because they "scale up the social control mechanisms that operate spontaneously" (p. 126) to ensure prosocial behavior in village-sized groups. Both Equatorial Guinea and Norway have oil resources. In Equatorial Guinea, almost all income from oil benefits the president and his close relatives. In Norway, income from oil is a common good secured in the Government Pension Fund, regulated to benefit current and future generations of Norwegians. Wilson's (1998) hypothesis is that natural selection favors altruistic groups over

\footnotetext{
${ }^{1}$ Carsta Simon, Oslo and Akershus University College of Applied Sciences, Norway, Department of Behavioral Sciences. Acknowledgements: I thank William M. Baum, Per Holth, Ingunn Sandaker, David Sloan Wilson, Nina Witoszek and my lab group Experimental analysis of behavior - Translational and conceptual research for their comments on earlier drafts of this paper. Contact: Postal address:Oslo and Akershus University College of Applied Sciences, Department of Behavioral Sciences, PO Box 4 St. Olavsplass NO-0130 Oslo, Norway. Email address: carsta.simon@hioa.no
} 


\section{ILLUMINATING NORDIC “CO-OPERATION”}

selfish groups. Thus, high degrees of sharing and cooperation are considered a core feature of wellfunctioning groups of differing degrees of complexity.

Taking the supposition that a lack of cooperation between and amongst societies lies behind many crises of the $21^{\text {st }}$ century (Sennett, 2012; Turchin, 2007; D. S. Wilson, S. Hayes, A. Biglan, \& D. Embry, 2014; D. S. Wilson, S. C. Hayes, A. Biglan, \& D. D. Embry, 2014; Wilson \& Hessen, 2014) as a point of origin, we may ask, what makes for cooperative behavior? Different from many evolutionary approaches to psychological phenomena, which regard mechanisms for behavior as their genuine subject matter (e.g. Rand \& Nowak, 2013), I here analyze cooperative behavior directly as a function of genetic and environmental factors. All behavior, including cooperation, is caused by nature and nurture, in other words, by selection during phylogeny and during ontogeny. Natural selection is slow, working across many generations of organisms. Selection during phylogeny illuminates why we are born with tendencies to engage in certain activities, or to readily acquire certain patterns of behavior. Selection of behavior during ontogeny illuminates how our behavior and events in our environment causally interact during our lives.

Understanding the nature of the feedback-loop between behavior and the environment will inform one of the main queries motivating the recent thorough analysis of successful Scandinavian Nations (Wilson \& Hessen, 2014; Wilson et al., 2016): Can the Nordic Model be generalized as a tool for solving the problems of other nations? Understanding the nature of the feedback-loop between cooperative behavior and the environment, means, inter alia, understanding the social control mechanisms that Wilson and Hessen set out to identify. Critics (e.g. Richerson, 2014) have expressed doubts by pointing to Norway's distinct history of small class differences, oil economy and high ethnic homogeneity. After all, $86 \%$ of Norway's population is of Norwegian descent. However, Wilson and Hessen suggest that despite those particular attributes, an analysis of Norway as a case of a cooperative nation may allow deriving "universal functional design principles" to coordinate action in groups. These principles originate in a list presented by the Nobel Prize ${ }^{2}$ winner Elenor Ostrom (Wilson, Ostrom, \& Cox, 2013). The list primarily consists of suggestions on how to structure the environment of groups to make them perform successfully.

Analysis of such functional "design principles" on the basis of a case study is a promising endeavor - to the extent that those "design principles" are not thought of as cookie-cutters that can be applied to other nations. Instead, identifying the function of such tools or "design principles" would allow for making new effective tools, adapted to the peculiarities of new cases. In the terminology of radical behaviorism, these "design principles" or "tools" describe contingencies between behavior and reinforcement and punishment. Rather than knowing a tool's particular structure, knowing what feature of the tool makes for its leverage may allow it to work in more heterogeneous countries with long histories of class differences and no oil. The leverage lies in the functional relation specifying the behavior-environment feedback system. The system is specified by the relationship between organisms' behavior and events in their environment. The nature of the relationship between cooperative behavior and environmental events, mostly consisting of social or socially mediated consequences, is an empirical question that a plethora of scholars have analyzed in controlled experiments (e.g. Baker \& Rachlin, 2001, 2002; Baum, Paciotti, Richerson, Lubell, \& McElreath, 2012; Jones \& Rachlin, 2009; Silverstein, Cross, Brown, \& Rachlin, 1998).

The possibilities to test the nature of the relationship on the level of nations are as limited as testing the causal role of natural selection in evolving and maintaining cooperation in Norway. Consequently, this paper undertakes to spot the connection between behavior and environmental

\footnotetext{
${ }^{2}$ The Sveriges Riksbank Prize in Economic Sciences in Memory of Alfred Nobel
} 
events in Norway, which may qualify as the sought-after "drivers towards better societies" (Wilson \& Hessen, 2014, p. 152). To limit the scope of the paper, the text focuses on Norway, and makes some comparisons to Sweden, although the 'Nordic Model' is typically defined as a system of economic and social policies common to all five Nordic countries. The term Nordic countries denotes the three Scandinavian countries of Denmark, Norway and Sweden, in addition to Finland and Iceland. There is an ongoing discussion (Dølvik, 2013b; Nordic Experiences, 2017) on whether we should speak about one or several Nordic Model(s) and to what extent the Nordic Models found in all three Scandinavian countries are alike and to what extent the Nordic Model also reflects the political agenda of the other two Nordic countries Finland and Iceland.

To shed light on the Nordic cultural-evolutionary puzzle of managing to maintain a dynamic equilibrium between competition and cooperation, the paper takes a two-step approach. First, it explains the workings of the empirically supported mechanism selecting cooperative behavior during an individual's lifetime. Second, particular traditional Norwegian and Swedish cultural characteristics are interpreted in the light of selection of cooperative behavior.

\section{Cooperation in the Light of Multi-Scale Selection During Ontogeny}

Multi-level-selection theory (Wilson \& Sober, 1998) constitutes an extension and specification of Darwinian selection, which predicts that selfish individuals outcompete cooperative individuals, whereas groups consisting of primarily cooperative individuals outcompete groups consisting of primarily selfish individuals. Evolutionary theorists (e.g. Krasnow \& Delton, 2016; Krasnow, Delton, Cosmides, \& Tooby, 2015; Richerson et al., 2015) currently debate whether multi-level selection can be part of the explanation of the equilibrium of cooperative and selfish behavior. In addition to multi-level selection, natural selection produced another selection mechanism, which allows behavior to adapt to the environment during the lifetime of organisms.

Human behavior is affected by environmental events. In the course of their lives, organisms learn to do more of what works. Since the overall time organisms can behave is limited, activities compete with one another for time. The competition results in selection of activities (Baum, 2013). What activities are selected during the lifetime of the individual depends on the relationship between activities and events that have gained their power to affect behavior during the lifetime of the organism as a result of many generations of natural selection.

Baum (2012) termed these events Phylogenetically Important Events. These events, such as food, mating opportunities, severe weather or parasites, either increase or decrease the chances of survival and reproduction. Phylogenetically Important Events (PIEs) are not to be understood as particular cutting-edge breakthroughs in human evolution such as upright walk or control over fire but as events that are traditionally said to function as reinforcers of behavior during the lifetime of the individual organism. These events are "phylogenetically important" in the sense that they affect fitness. Behavior that enhances advantageous PIEs or mitigates disadvantageous PIEs is selected during phylogeny and during ontogeny, by parallel selection processes. Which particular events can enter into a contingency with behavior depends on the environment in which the species evolved. Because of humans' long history of living in groups (Diamond, 2012), many of those events are social, or socially mediated, and indirectly related to reproduction and survival.

Stimuli correlated with PIEs become PIE-related conditional inducers of behavior. Depending on the context, such events could, for example, be another person's help, smile, frown, verbal responses or eye-contact (Baum, 2012; Simon \& Baum, 2017). These PIE-proxies resemble the 


\section{ILLUMINATING NORDIC “CO-OPERATION”}

concept of conditional reinforcers to the extent that their effect is not innate but contingencies need to create covariances between activities, PIEs and PIE-proxies, to make PIE-proxies effective. Historically, a reinforcer was said to strengthen a response when the reinforcer occurs contiguously with the response (Skinner, 1948; Thorndike, 1911/2000). Research (Baum, 2012; Rescorla, 1968, 1988; Simon \& Baum, 2017) suggests that contiguity between activities and PIEs does not suffice to induce behavior, but that PIEs and activities need to enter into a contingency, which may be even more effective if the activity and the PIE, or PIE-proxy occur in temporal proximity. Yet, temporal closeness of events does not define a contingency. Instead, two events, such as a PIE and an activity, are said to be in a contingency if the probability of event A differs, given event B. Work and wage are in a contingency if getting paid is conditional on or more likely when working, not if the two events are independent of each other.

PIEs resemble discriminative stimuli in the sense that no one-to-one relation exists between induced behavior and the inducing event. The concept of PIEs largely overlaps with discriminative stimuli and reinforcers. However, contrary to discriminative stimuli and reinforcers, the concept of PIEs attributes some of the stimulus control to phylogeny. The overlap of the concept of PIEs with both discriminative stimuli and reinforcers emphasizes that selection of behavior during ontogeny occurs because activities and environmental events enter into an iterative feedback loop rather than a linear three-term contingency (Baum, 1973, 1981).

Many situations in human life present choices between: (a) alternatives beneficial to an individual; and (b) alternatives that are less beneficial to the individual but that would nevertheless be advantageous to the individual and the group if chosen by many individuals. Choices of the latter alternative are generally considered cooperative. If I pay taxes that pay people to clean the streets, I benefit from clean streets, just as the other members of my community. If, however, I am the only one paying taxes, I largely invest with no benefit. This means that the relationship of an individual's behavioral pattern with PIEs may depend on the behavior of other group members. Cooperation is a valuable temporally-extended pattern of behavior that may be learned and maintained over an individual's lifetime. It needs no special inherited mechanisms, besides those mechanisms that make our behavior susceptible to social consequences (Simon, 2016b) .

Just as group selection theory (Wilson \& Sober, 1998) postulates more than one level of natural selection, organism's behavior may be selected by its relationship with PIEs at more than one level during ontogeny. Selection may act on individual activities, and on groups of activities that is, extended activity patterns. Extended behavioral patterns, which are a unit of ontogenetic selection, are exhibited by individuals, as well as, by groups (Simon, 2016a). It is even conceivable that the same pattern is exhibited by individuals or groups. I may pick up all trash lying on my street, or I may do this together with my neighbors. Then again, a group's cooperative behavior might result in an aggregated product, which none of the individual members could have produced by themselves and which reinforces everyone's activity (Glenn, 2003). If silence is a valued good in a shared working space, all workers have to refrain from talking. Silence is not maintained if I am the only one who leaves the working space to take phone calls, no matter how often I go out. Just as a less extended activity maximizing benefit to the individual in the short term may conflict with a more extended activity pattern of behavior maximizing advantageous PIEs to the individual over time, so a less extended act maximally beneficial for one individual may conflict with a maximally beneficial pattern of acts exhibited by a group (Rachlin, 2002).

Typically, less complex levels of selection tend to undermine more complex levels (Wilson \& Sober, 1998). Natural selection has seen to it that behavior is highly susceptible to strong associations with PIEs close in time. Impulsiveness was and still is adaptive in many situations. 


\section{SIMON}

Temporally extended, abstract behavioral patterns, be it cooperation (helping someone) or selfcontrol (e.g. not smoking, generally being sober, eating a good diet), are more difficult to establish and to maintain than less extended activities such as selfish decisions (refusing to help) or impulsive behavior (e.g. smoking, yet another drink, and yet another dessert, Locey, Jones, \& Rachlin, 2013; Rachlin, 1995, 2002, 2004, 2015; Rachlin, 2016; Rachlin \& Locey, 2011). These are the workings of multi-scale selection during ontogeny.

Individual acts of cooperation, each of which may be of no benefit (or of possible harm) to the actor, may nevertheless be beneficial when repeated over time and by several people. An individual's non-reciprocal cooperative act, such as refraining from the exploitation of a community's common resource, may be disadvantageous for the individual's relative fitness.

Cooperation and defection have frequently been studied experimentally by means of what Poundstone (1992) called the prisoner's dilemma game. In a two-player scenario, each player chooses between cooperation and defection. If both cooperate, this is most advantageous for both; if both defect, this is somewhat advantageous for both; if one cooperates and one defects, this is strongly disadvantageous for the cooperator and strongly advantageous for the defector. The game scenario captures the "dangerous" aspect of cooperative choices. Locally, defection is the better option for the individual but on average and for the group or dyad, cooperation is the better option.

Because each selfish decision is individually preferred to each cooperative decision, people can benefit from cooperative behavior only when they are committed to a cooperative pattern of acts and refuse to make decisions on a case-by-case basis. Most of us are committed to paying for our goods before leaving a shop and do not decide whether or not to steal based on the current chances of being caught. Analyzing the relationship of patterns of cooperative behavior and PIEs will illuminate how a commitment to cooperative behavior patterns is maintained in Norwegian culture.

Opportunities to experimentally test whether or not the behavior of nations and their citizens results from their contingency with PIEs occurring during the organisms' lifetimes, along with multiple levels of natural selection, are limited. Thus, we are bound to tell what we find to be a likely story and to test its implications. If multi-level phylogenetic and multi-scale ontogenetic selection of behavior acted and still act to make Scandinavian nations successful by fostering cooperation, we should, in Scandinavian nations, more than in other nations, find an equilibrium of selfish and cooperative behavior. We may expect to find this equilibrium in the behavior of groups, and of the individuals they consist of, as well as of the larger groups they constitute. Not only should we find Scandinavian political structures, such as the welfare system, but even more so characteristic cultural practices fostering cooperation among Scandinavians, as well as competition between nations, including among Scandinavian nations and particularly between Scandinavians and other nations. Political structures and cultural practices are effective or ineffective based on the contingency between the behavior of organisms and PIEs. This paper discusses the functions of some examples of cooperative Scandinavian cultural practices and policies in the light of their contingencies to PIEs. Since the identification of those contingencies is a piece in the puzzle of why Scandinavian countries function so well, it will also contribute to answering the widely debated (Richerson, 2014; Wilson \& Hessen, 2014; Witoszek, 2014) bigger question of transferability of systems to other nations. 


\section{ILLUMINATING NORDIC “CO-OPERATION”}

\section{Norwegian Culture Fostering Cooperation: Evidence of Cooperation in Scandinavian Countries from a Selectionist Perspective}

This paper attempts to give a behavior analytic interpretation of the economic and social policies in the Nordic countries with an emphasis on Sweden and Norway. Since the success of state models is determined by the behavior of its people, this paper will not only consider the systemic characteristics of Scandinavian policies discussed extensively elsewhere (e.g. Christiansen, 2006; Dølvik, 2013a; Greve, 2007; Hilson, 2008; Kvist, 2012; Midttun et al., 2011), but will also focus on cultural practices, which are characteristically Scandinavian behavioral patterns (see Simon \& Baum, 2012, for a more extended definition of culture). Thus, instead of drawing a demarcation line between policies and behavioral tendencies, this paper takes the contingencies between PIEs and behavioral patterns of individuals and of groups with different degrees of complexity as its starting point.

\section{Interrelatedness of Policies and Practices}

Subjugating individuality in favor of the collective is a cultural trait characterizing group coherence and cooperation of group members. This tendency is reflected in policies, as well as behavioral norms, which both traditionally prosper in Scandinavia as they go hand in hand. An example of the interrelatedness of official policies and cultural practices is that Scandinavian policies allow almost no investment in elite sponsorship, and outstanding students customarily may not skip grades in school. This goes hand in hand with a behavioral norm followed by teachers: They encourage outstanding students to help others when having finished their tasks. Just as a welfare state fosters low class differences, the grade-skipping policy and the behavioral classroom norm together foster lower differences in achievements among individuals and ensure the group to perform well.

\section{The Contingencies of Trust}

The political structures of Scandinavian welfare states, allowing for relatively low classdifferences, go along with low criminality which, in turn, allows for high degrees of trust (Berggren \& Trägårdh, 2011; Edlund, 1999), a behavioral norm. Partly, people leave their doors unlocked and behave in other ways that we call "trusting" because such behavior does not substantially positively correlate with losing resources but with being able to spend time on other beneficial activities. Not only do Scandinavians lead in statistics of trusting other inhabitants, but also in trusting their governmental systems. Most Scandinavians readily pay their high taxes (Buehn \& Schneider, 2012; OECD, 2016; Tsakumis, Curatola, \& Porcano, 2007) because the contingency between paying and embezzlement is weak; whereas the contingency between paying and useful infrastructures is strong. Most people trust the government to the extent that they do not check their tax return (Chaffey, 2017). There is a strongly visible, reliably occurring contingency between defective behavior and actual sanctions. For example, Norwegian media currently present the possible conviction of the corrupt police officer Eirik Jensen to the highest possible sentence of 21-year imprisonment as their main headline (e.g. NRK, 2017).

Also, trust in sharing personal data with governmental agencies is comparably high due to particularly low association with misuse. Participation in direct debit, an agreement allowing companies to automatically withdraw money from your account, replacing actively paying one's 
bills, is highest in Scandinavia (European Central Bank, 2015). As the Norwegian prime minister Gro Harlem Brundtland phrased it in her 1992 New Year's speech "Det er typisk norsk å være god" ("It's typical Norwegian to be good/kind/competent").

The word "typisk" (English: "typical") points to an important aspect of the concept of contingency between behavior and PIEs. Contingencies create a correlation between events and select behavior based on a comparison of two or more occasions. For selection to occur, the probability of a PIE in the presence of behavior needs to be different from the probability in the absence of behavior. In order to become susceptible to probability, the behavior needs to recur. Since accidental contingencies would require at least two accidental conjunctions, they should be rare (Baum, 2012). Thus, ontogenetic selection of behavior is likely to adapt activities to actual causal relations, rather than to coincidences. This may illuminate why a long-standing pattern of trust, an experience of typical goodness, is usually not discontinued by single instances of contradictory events such as the dramatic security failure that allowed the terrorist attack on July 22, 2011, resulting in 77 deaths (Witoszek, 2014).

\section{Cooperation and The Law of Jante}

The Danish writer Axel Sandemose in the now famous novel "A Fugitive Crosses His Tracks" (1933/1936) pinpointed a set of unstated behavioral norms Scandinavians tend to follow. The set consists of ten principles he called The Law of Jante (Norwegian Bokmål "Janteloven"). This "law" is not a formal regulatory tool or legal instrument, but rather an explication of social contingencies and partly an ethnic stereotype. Table 1 divides the ten principles of the Law of Jante into two main themes, which reflect to what extent following that behavioral code fosters or inhibits cooperative behavior. Theme 1, in the left column, may be summarized as "don't think you are better than us". Theme 2 , in the right column, may be summarized as "don't think you are worth anything". Theme 1 may support group coherence and cooperation by encouraging one to regard all group members as worth equally much, instead of some being better than others. Theme

Table 1. The Law of Jante sorted as two themes, original numeration (Sandemose, 1933)

\section{Theme 1: As Good As}

"don't think you are better than us"

1. You're not to think you are smarter than we are.

3. You're not to convince yourself that you are better than we are.

5. You're not to think you know more than we do.

7. You're not to think you are more important than we are.

9. You're not to laugh at us.

\section{Theme 2: Impair the individual}

"don't think you are worth anything"

2. You're not to think you are anything.

4. You're not to think you are as good as we are.

6. You're not to think you are good at anything.

8. You're not to think anyone cares about you.

10. You're not to think you can teach us anything. 


\section{ILLUMINATING NORDIC “CO-OPERATION”}

1 indicates contingencies between behavior distinguishing a group member from the group and disadvantageous PIEs. This theme may function to signal to individuals that behavioral divergence from the group mean may be socially punished.

Theme 1 indicates the contingency of moderate behavior with social consequences. To be a good Scandinavian group member, one is advised to behave in a temperate, instead of an extreme manner. The Swedish adjective lagom, meaning something like "just right", "not too much and not too little", lacks equivalents in other languages (Barinaga, 1999) and has been taken to reflect Swedish moderateness. Folk tales, for example, teach Theme 1 to Norwegian children. Askeladden, the main character in many Norwegian folktales, is not a superman or hero, nor someone boasting about his achievements. He helps the needy and puts the mighty in their place (Witoszek \& Hanssen, 1998). In other western cultures, parents focus more on making their children believe in themselves (the opposite extreme of Theme 2) than on making them behave moderately (Theme 1). In the Australian 2015 film adaptation of the Norwegian play Vildanden ("The Wild Duck", Ibsen, 1884), titled "The Daughter" (Stone, 2015), the screenplay writer added a dialog between the main character, the teenager Hedvig, and her ostensive father. The dialog serves to illustrate to the movie audience what an excellent whole-hearted father-daughter relationship they have: Hedvig: "You are the best", Father: "No, you are the best", Hedvig: "No, it's you who is the very best". Such a dialog (here paraphrased) appears natural in the Australian movie setting, but would have been odd if it had occurred in the original Norwegian setting of the play.

An individual fully embracing The Law of Jante's Theme 2, however, would not be an especially cooperative group member but would rather be diagnosed with clinical depression reflecting highly maladaptive behavior, disadvantageous for the individual as well as the group. Communication resembling Theme 2 does not encourage behaving so as to generate positive consequences for the whole group, but rather resembles what has been denoted as "crap mentality" or the "tall poppy syndrome" (Feather, 1989), which signifies behavior serving to hinder other group members in their achievements. Crap mentality might be regarded as the opposite of cooperation. It reflects selfish behavior, giving advantages to the individual, threatening the success of the group as a whole.

In Scandinavian countries, as compared to other countries, cooperation may be regarded as more common than crap mentality. Cooperative behavior, reflected in Theme 1, is maintained by strong positive associations with social PIEs, such as approval and affection, giving feedback subtly, being humble about one's own achievements, generally expressing feelings subtly, or giving group members who made mistakes another chance as a group member.

One way of safeguarding the achievements of groups as wholes may be to arrange for an equality of results, rather than equality of the means to achieve results. As anyone who has lived or worked together with people with differing abilities or interests can confirm, a group's distribution of costs and benefits do not need to be equal to be fair. In Norway, equality of results is, for example, approached by offering "leadership training for women only" (e.g. Folkeuniversitetet, 2016; Industrienergi, 2016) and quotas for educational programs (Norwegian Ministry of Education and Research, 2016). Such programs discriminate against men as a subgroup by prohibiting their participation, but they ensure the success of the group as a whole by selectively providing contingencies only promoting activities of those group members whose behavioral change is assumed to increase performance of the group as a whole. Based on the assumption that groups who have variation, for example, in leaders' sexes, will outperform groups with homogeneous leaders, the behavior of the underrepresented group members is shaped by 
contingencies with advantageous PIEs, whose availably is restricted to the underrepresented group members. A leadership training, in which participation is restricted to women, for example, may provide contingencies between social PIEs such as praise and, let us say, taking risky decisions, shaping only the behavior of women into more effective leadership (of which "taking risky decisions" may be a part, for the sake of this example). The well-being of society prevails over providing equal treatment to everyone. Gender quota or admission criteria for education change the overall contingency between investment (e.g. of time) and access to resources. Such affirmative actions or disadvantage compensations on one level may benefit competition allowing for innovations on another level.

\section{Groups on Different Levels}

Strong group identity is one of the features of well working, cooperative, groups (Wilson et al., 2013). Identity requires demarcation of an in-group and an out-group. The in-group/out-group demarcation is achieved by Scandinavian groups on several nested levels. Reflecting upon the Norwegian "Regime of goodness" (Witoszek, 2011) in the light of multi-level selection, one sees that policies maintain one set of contingencies between PIEs and activities of the Norwegian ingroup; whereas, they maintain another set of contingencies between activities of the world population (mainly consisting of a non-Norwegian outgroup) and PIEs. An example of such demarcation is Norway's investment of oil profits into a long-term pension fund, which is a favorable PIE potentially available to the inhabitants of Norway. At the same time, Norway supports non-sustainable industries such as coal mining, which are disadvantageous for the planet and contributes to the further use of oil in the nations to which Norway sells it, regardless of the environmental consequences. Belonging to the group of Norwegians means to be eligible to the protection and resources of the group.

The remarkably low rate of $2 \%$ veganism/vegetarianism (contrasted to $10 \%$ in Sweden, Norwegian Vegan Society, 2012; The Local, 2014), going along with high carbon dioxide exhaustion (Fiala, 2009; Röös, Sundberg, Tidåker, Strid, \& Hansson, 2013), and continuous whale hunt may be other examples resulting from policies benefitting Norwegians and harming the planet. Advantageous PIEs are accessible contingent on residency. On another level, this ingroup/out-group demarcation, is not only reflected in political decisions such as not joining the Euro currency union, and not having a currency union between Scandinavian countries, but also in a common word choice of Scandinavians talking about "us and Europe" and going on vacation "in Europe" (when traveling to a European country outside of the Nordic countries).

The Law of Jante (primarily Theme 1) indicates the contingency between PIEs and within, rather than between, group behavior. As in many countries, Norwegians have a culture fostering pride, not only of being Scandinavian but also of being Norwegian. Hardly a family home or cabin does not have a flagpole. Demarcation of belonging to the Norwegian in-group is moreover attained by the celebration of the Norwegian national day, May $17^{\text {th }}$, when people dress in livery and schools organize their students to go in parades waving Norwegian flags.

Identification with groups of different degrees of complexity is mirrored in a differentiation of being a Norwegian, not a Swede or Dane in some contexts, such as when telling jokes based on stereotypes about the other Scandinavian nations. To a Swede, the presence of another Swede may be a context (or motivating operation), which signals that telling a joke about non-Swedish Scandinavians may lead to social PIE-proxies such as laughter and approval. In other contexts, however, when contrasted to "the rest of the world," Scandinavians act very much as a unit. 


\section{ILLUMINATING NORDIC “CO-OPERATION”}

Swedes who (following Poles) represent the second largest group of immigrants to Norway are often not regarded as foreigners since they hardly face cultural or language challenges. Norwegians meet Swedish immigrants mainly with positive prejudices such as being hardworking and service oriented. The context-dependent in-group/out-group role of Swedes in Norway is mirrored, for example, in the current discussion of whether a well-known graffiti on a wall in Oslo saying "Party-svensker. Go home!" is racist or not (Kvittingen, 2015). The term "party-svensker" alludes to the high number of young Swedish adults who come to Norway to work and to party. No question that it would have been regarded as racist if it had been about any other group of immigrants but Swedes.

\section{A History of Group Demarcation}

In the late 1800 's, when Sweden ruled Norway and Denmark had ruled Norway for 400 years, the movement toward independence demanded an identification of the genuine Norwegian. The in-group building was pursued actively by trying to identify "typical Norwegian" culture. Norwegian intellectuals were given scholarships to identify and create a Norwegian identity. Among those intellectuals who traveled around to collect Norwegian traditions, were Henrik Ibsen and Peter Christen Asbjørnsen (Strøksnes, 2016). Asbjørnsen received financing for writing down tales from different regions in Norway, resulting, among other things, in Asbjørnsen and Moe's famous collection of Norwegian folktales $(1843 ; 1844)$.

Although Norway has one of the longest and most beautiful coastlines and has long relied on fishery as its main industry, the commissioned intellectuals identified "typical" Norwegian culture by objects and traditions found in the (genetically and culturally) isolated valleys in Eastern Norway. Local peasant traditions were regarded as the most stable because the opportunity to meet new practices (or genes) was more limited for inland farmers than for sailors. So, intellectuals like Asbjørnsen fostered group-identification by identifying typical Norwegian traditions (Strøksnes, 2016).

Moreover, the attempt to preserve something that demarcates the difference from the other Scandinavian countries is reflected in the strong protection of Nynorsk. Nynorsk is one of two officially equally accepted Norwegian writing languages, used by $7-15 \%$ of Norwegians as their main writing language. When Denmark ruled Norway, all writing was required to be in Danish. From written Danish, Bokmål, developed. Today, at least $85 \%$ of the Norwegian inhabitants, write primarily in Bokmål. Maintaining Nynorsk means fostering a written language, closer to original Norwegian dialects and clearly differing from Danish - a language that was not, once upon a time, superimposed by a competitor, the neighboring country.

\section{Pragmatism}

Bokmål is a concise and pragmatic language with limited possibilities for nuances, embellishment or politeness. Scandinavians' behavior has repeatedly been described as pragmatic (Bourrelle, 2015; Witoszek \& Hanssen, 1998). As the rocket scientist and comedian Julien S. Bourrelle (2015) illustrates in his Social Guidebook to Norway, Norwegians are practical, purposeful and efficient in their activities, which they do in isolated "bubbles". Those "bubbles" hardly overlap or interact, and there are rigid norms framing social activities, as well as a strong sense of community. Everyone is expected and often willing to contribute. 


\section{SIMON}

More than people in other nations, Norwegians tend to organize around activities in clubs. Rather than inviting each other home for dinner, people get to know each other through commonly organized activities such as skiing, hiking or making music. In proportion to population, the Norwegian Humanist Association (HEF) is the world's largest secular humanist association, with $1.7 \%$ of the Norwegian population being members (Sentralbyrå, 2016). Activities organized in clubs and by HEF function in many ways as religions do in other countries. That is, they are also in contingencies with fitness, advantageous social events, and community building. At the same time, these activities commonly enter into a contingency with even more positive PIEs. Going on a hike with other hiking club members might meet a person's social needs as much as joining a church service, but it is, at the same time, a health-promoting activity. Norwegians' widespread appreciation of nature (Aasetre, Kleiven, \& Kaltenborn, 1994; Dervo et al., 2014) surely reflects a cultural practice promoting health (Bischoff, Marcussen, \& Reiten, 2007; Koksvik, 2009; Morstad, 2011; Worum, 2015).

Groups, be it of those who regularly meet to go hiking or of those who commonly own a building in which they each have their individual apartment, are fostered by another typical Norwegian practice, reflected in a term lacking an equivalent in other languages: dugnad. The term refers to meeting up to commonly do work that benefits the whole group (such as renovating the hiking cabin, cleaning the apartment building) and is usually followed by a social gathering. The association between participation in dugnad and its social and economic consequences may be more or less explicit; for example, the author's contract for her apartment, lists yearly dugnadparticipation as an obligation in line with paying the monthly rent. Dugnad is originally voluntary group work by definition, but the term is used in broader and broader contexts. Wikipedia is also regarded as a dugnad-project (although it constitutes a full-time job for some and does not involve physical gatherings).

\section{Same Same Scandinavia?}

Even if the Scandinavian nations have enough commonalities that they could be treated as a unit up to this point of the paper, of course, they are not alike. The countries' histories differ, and so do their cultural practices. Norway, for example, in contrast to Sweden, has never had nobility, and might therefore, in some respects, require less stringent contingencies between behavior and PIEs for ensuring equality than, for example, Sweden. For instance, Norwegian intellectuals (e.g. Knausgård, 2015) have criticized the high levels of political correctness ("Åsiktskorridor", English: "Corridor of opinion") in Swedish media and private communication. As pointed out in the discussion of The Law of Jante, contingencies between extreme behavior, such as expressing extreme opinions, and social punishment may ensure group coherence by creating an impression of consensus and protecting the weak. Limiting variation restricts what can be selected. As evolution is an ongoing process and Scandinavian countries are facing challenges just as the rest of the world, one may question how beneficial such limitation practices may be.

\section{Concluding Comments}

Where English (and Swedish) speakers "have skeletons in the closet," Norwegians "have pigs in the forest" (Norwegian bokmål: "å ha svin på skogen”) - except that they do not; for the most part. As this paper aimed to point out, Scandinavian culture features an exceptional amount of contingencies fostering cooperation, acting against selfish, reprobate behavior and against keeping misdeeds concealed (after all, every Norwegian can look up online how much their neighbors earn, 


\section{ILLUMINATING NORDIC “CO-OPERATION”}

Skatteetaten, 2016)). The saying "to have pigs in the forest" has been attributed to two different Norwegian historical origins, both representing tragedy of the commons scenarios. Possibly, the saying originates from a time when tax collectors visited farms to count the number of animals a farmer owned, which was the basis for how much tax he had to pay. A farmer hiding his pigs in the forest cheated on his community by paying fewer taxes (Evensberget \& Gundersen, 1983). Alternatively, the saying may have originated in a setting where several community members shared a forest area in which their cattle grazed while some farmers overexploited the area by also letting their pigs browse and damage the forest (Lomheim, 2016).

This paper neither attempts to sweep the challenges Scandinavian countries are facing under the rug, nor to claim that levels of cooperation are today at their historical peak; the aim of this paper was to pinpoint and interpret some comparatively well-working Scandinavian practices. Much works well, not all is perfect (Midttun et al., 2011). To offer an explanation for traditionally high levels of cooperation in Norway, this paper discussed diverse examples shedding light on partly conflicting contingencies between PIEs and the behavior of individuals, of small groups such as families, of larger groups such women or the Norwegian population, the Scandinavian population, or the population of our planet. In contrast to the common practice of analyzing societies and smaller groups separately and by their own means, this paper interpreted the behavior of Scandinavian groups with different degrees of complexity in the light of a common ontogenetic learning mechanism for cooperative behavior. This analog to the biological mechanism of multilevel group selection during phylogeny, ontogenetic multi-scale behavioral selection, not only generates retrospective hypotheses about why and how cooperative behavior has developed in Norway, but also guides interventions.

The logic of ontogenetic selection suggests that to facilitate cooperation in other countries, we may provide contingencies between behavior and PIEs that resemble effectively working contingencies, for example, found in Scandinavia. It goes without saying that the design of these contingencies is an empirical question. Further investigations in laboratory studies and in other field contexts are required to test the hypotheses this paper put forward by means of interpreting unique Scandinavian behavioral patterns and their functional relation to controlling environmental events. These functional relations are no blueprint-tools that can be derived from short-term observation but need to take account of peoples' histories, which consists of exposure to former or still ongoing relationships between behavior and PIEs. Whereas, high tax-financed welfare seems to maintain low class differences and low criminality in Norway, increasing the wages of checkpoint staff demanding bribes from travelers' in Ghana, has been shown to increase the sums of money the checkpoint staff demanded (Agbota, Boge, \& Dzorgbo, in preparation). "Zooming out," or temporally extending the picture, taking history into account, might give a more reliable picture of functional relations between cooperation and PIEs.

\section{References}

Aasetre, J., Kleiven, J., \& Kaltenborn, B. P. (1994). Friluftsliv i Norge-Motivasjon og atferd. [Outdoor Activities in Norway - Motivation and Behavior]. NINA oppdragsmelding, 309, 1-56.

Agbota, T. K., Boge, K., \& Dzorgbo, D.-B. (in preparation). A behavior analytic view on wage increment as an anticorruption measure: A study of police corruption at road checkpoints in Ghana.

Asbjørnsen, \& Moe. (1843). Samlede Norske Folkeeventyr ved Asbjørnsen og Moe In: Christiania.

Asbjørnsen, P. C., \& Moe, J. E. (1844). Norske Folkeeventyr: II, 1.

Baker, F., \& Rachlin, H. (2001). Probability of reciprocation in repeated prisoner's dilemma games. Journal of Behavioral Decision Making, 14(1), 51-67. 


\section{SIMON}

Baker, F., \& Rachlin, H. (2002). Teaching and learning in a probabilistic prisoner's dilemma. Behavioural processes, 57(2), 211-226. doi:10.1016/S0376-6357(02)00015-3

Barinaga, E. (1999). Swedishness through lagom. Can words tell us anything about a culture. Stockholm: Centre for Advanced Studies in Leadership.

Baum, W. M. (1973). The correlation-based law of effect. Journal of the Experimental Analysis of Behavior, 20(1), 137-153.

Baum, W. M. (1981). Optimization and the matching law as accounts of instrumental behavior. Journal of the Experimental Analysis of Behavior, 36(3), 387-403.

Baum, W. M. (2012). Rethinking reinforcement: Allocation, induction, and contingency. Journal of the Experimental Analysis of Behavior, 97(1), 101-124. doi:10.1901/jeab.2012.97-101

Baum, W. M. (2013). What counts as behavior? The molar multiscale view. The Behavior Analyst, 36(2), 283.

Baum, W. M., Paciotti, B., Richerson, P., Lubell, M., \& McElreath, R. (2012). Cooperation due to cultural norms, not individual reputation. Behavioural processes, 91(1), 90-93. doi:https://dx.doi.org/10.1016/j.beproc.2012.06.001

Berggren, H., \& Trägårdh, L. (2011). Social trust and radical individualism: the paradox at the heart of Nordic capitalism. Paper presented at the Shared norms for the new reality: the Nordic way. World economic forum Davos, Stockholm, Sweden.

Bischoff, A., Marcussen, J. C., \& Reiten, T. (2007). Friluftsliv og helse: en kunnskapsoversikt. [Outdoor Activities and Health - An Overview of Knowledge].

Bourrelle, J. S. (2015). The Social Guidebook to Norway (Vol. 2). Norway: Monda.

Buehn, A., \& Schneider, F. (2012). Size and Development of Tax Evasion in 38 OECD countries: What do we (not) know? CESifo Working Paper Series No. 4004. Available at SSRN: https://ssrn.com/abstract=2181359.

Chaffey, P. (2017). Talk by the Norwegian State Secretary / Minister of local government and modernization. Paper presented at the Oslo Atferdsanalytisk Konferense, Oslo, Norway.

Christiansen, N. F. (2006). The Nordic model of welfare: a historical reappraisal. University of Copenhagen, Denmark: Museum Tusculanum Press.

Dervo, B. K., Skår, M., Köhler, B., Øian, H., Vistad, O. I., Andersen, O., \& Gundersen, V. (2014). Friluftsliv i Norge anno 2014-status og utfordringer. [Outdoor Activities in Norway anno 2014 - status quo and challenges].

Diamond, J. (2012). The world until yesterday: What can we learn from traditional societies? : Penguin.

Dølvik, J. E. (2013a). Grunnpilarene i de nordiske modellene: et tilbakeblikk på arbeidslivs-og velferdsregimenes utvikling.

Dølvik, J. E. (2013b). Grunnpilarene i de nordiske modellene: et tilbakeblikk på arbeidslivs-og velferdsregimenes utvikling. Oslo, Norway: Fafo.

Edlund, J. (1999). Trust in government and welfare regimes: Attitudes to redistribution and financial cheating in the USA and Norway. European Journal of Political Research, 35(3), 341-370. doi: 10.1111/1475-6765.00452

European Central Bank. (2015). Payment Statistics for 2014 [Press release]

Evensberget, S., \& Gundersen, D. (1983). Bevingede ord. Oslo, Norway: Kunnskapsforlaget.

Feather, N. T. (1989). Attitudes towards the high achiever: The fall of the tall poppy. Australian Journal of Psychology, 41(3), 239-267.

Fiala, N. (2009). How meat contributes to global warming. Scientific american, 300(3), 72-75.

Folkeuniversitetet. (2016). Kvinner og ledelse. Retrieved from www.folkeuniversitetet.no/Yrkesrettede-utdanningerog-kurs/OEkonomi-administrasjon-og-ledelse/Kvinner-og-ledelse

Glenn, S. S. (2003). Operant contingencies and the origin of cultures. In Behavior theory and philosophy (pp. 223242). New York: Springer US.

Greve, B. (2007). What characterise the Nordic welfare state model. Journal of Social Sciences, 3(2), 43-51. doi: 10.3844 jssp.2007.43.51

Hilson, M. (2008). The nordic model: Scandinavia since 1945. London, UK: Reaktion books.

Ibsen, H. (1884). Vildanden. Copenhagen, DK: Gyldendal.

Industrienergi. (2016). Kvinner viser vei. Retrieved from https://www.industrienergi.no/kurs/sola-programmetmodul-1-min-rolle-som-leder-og-tillitsvalgt/

Jones, B. A., \& Rachlin, H. (2009). Delay, probability, and social discounting in a public goods game. Journal of the Experimental Analysis of Behavior, 91(1), 61-73. doi:10.1901/jeab.2009.91-61

Knausgård, K. O. (2015). Karl Ove Knausgårds rasande attack på Sverige. DN.kultur. Retrieved from http://www.dn.se/kultur-noje/kulturdebatt/karl-ove-knausgards-rasande-attack-pa-sverige/ 


\section{ILLUMINATING NORDIC “CO-OPERATION”}

Koksvik, E. (2009). Naturopplevelse, friluftsliv og vår psykiske helse. Oslo, Norway: Nordic Council of Ministers/Miljøverndepartementet.

Krasnow, M. M., \& Delton, A. W. (2016). The sketch is blank: no evidence for an explanatory role for cultural group selection. Behav Brain Sci.

Krasnow, M. M., Delton, A. W., Cosmides, L., \& Tooby, J. (2015). Group cooperation without group selection: Modest punishment can recruit much cooperation. PloS one, 10(4), e0124561.

Kvist, J. (2012). Changing social equality: the Nordic welfare model in the 21st century. Bristol, UK: Policy Press.

Kvittingen, I. (2015). Reagerer ulikt på å bli kalt partysvenske. forskning.no. Retrieved from http://forskning.no/kultur-innvandring-kulturhistorie-samfunn/2015/02/liker-og-hater-bli-kalt-partysvensker

Locey, M. L., Jones, B. A., \& Rachlin, H. (2013). Self-control and altruism. In G. J. Madden, W. V. Dube, T. D. Hackenberg, G. P. Hanley, \& K. A. Lattal (Eds.), APA handbook of behavior analysis, Vol. 1: Methods and principles (pp. 463-481). Washington, DC, US: American Psychological Association.

Lomheim, S. (2016, 11.12.) Språkteign/Interviewer: T. Myhre. Språkteign, NRK, Oslo, Norway.

Midttun, A., Witoszek, N., Joly, C., Karlsson-Vinkhuyzen, S., Olsen, P. I., Olsson, L., . . Østergård, U. (2011). The Nordic model: is it sustainable and exportable. CERES Working Papers, 2020110309.

Morstad, E. B. (2011). Natur og friluftsliv i rehabilitering - en kartleggingsstudie. (Master's Thesis), Norwegian University of Life Sciences, Ås. Retrieved from https://brage.bibsys.no/xmlui/handle/11250/186059?show=full

NordicExperiences, C. G. C. (2017). Global Challenges - Nordic Experiences. Paper presented at the Global Challenges - Nordic Experiences, Oslo, Norway. http://www.uio.no/english/research/strategic-researchareas/nordic/news-and-events/events/conferences/2017/global-challenges/programme.html

Norwegian Ministry of Education and Research. (2016). Opptakskvoter. Retrieved from http://www.samordnaopptak.no/info/opptak/opptakskvoter/

Norwegian Vegan Society. (2012). The Nordic market for vegetarian food on the rise. Retrieved from www.issuu.com

NRK. (2017). Rettssaken mot Eirik Jensen. Retrieved from https://www.nrk.no/nyheter/rettssaken-mot-eirik-jensen1.13307131

OECD. (2016). Tax revenues fall in OECD countries. Retrieved from http://www.oecd.org/general/taxrevenuesfallinoecdcountries.htm

Poundstone, W. (1992). Prisoner's dilemma: John von Neuman, game theory, and the puzzle of the bomb. In: Doubleday, New York.

Rachlin, H. (1995). Self-control: Beyond commitment. Behavioral and Brain Sciences, 18(1), 109-121. doi: $10.1017 / \mathrm{S} 0140525 \mathrm{X} 00037602$

Rachlin, H. (2002). Altruism and selfishness. Behavioral and Brain Sciences, 25, 239-250. doi: $10.1017 / \mathrm{S} 0140525 \mathrm{X} 02000055$

Rachlin, H. (2004). The science of self-control. Cambrige, MA, USA: Harvard University Press.

Rachlin, H. (2015). Choice architecture: A review of why nudge: The politics of libertarian paternalism. Journal of the Experimental Analysis of Behavior, 104, 198-203. doi:10.1002/jeab.163

Rachlin, H. (2016). Self-Control Based on Soft Commitment. The Behavior Analyst, 39(2), 259-268. doi: $10.1007 / \mathrm{s} 40614-016-0054-9$

Rachlin, H., \& Locey, M. (2011). A behavioral analysis of altruism. Behavioural processes, 87(1), 25-33. doi:10.1016/j.beproc.2010.12.004

Rand, D. G., \& Nowak, M. A. (2013). Human cooperation. Trends in Cognitive Sciences, 17(8), 413-425. doi:10.1016/j.tics.2013.06.003

Rescorla, R. A. (1968). Probability of shock in the presence and absence of CS in fear conditioning. Journal of comparative and physiological psychology, 66(1), 1-5.

Rescorla, R. A. (1988). Pavlovian conditioning: It's not what you think it is. American Psychologist, 43(3), 151.

Richerson, P. (2014). Comment on Blueprint for the Global Village. Cliodynamics: The Journal of Quantitative History and Cultural Evolution, 5(1), 136-140.

Richerson, P., Baldini, R., Bell, A., Demps, K., Frost, K., Hillis, V., . . Newson, L. (2015). Cultural group selection plays an essential role in explaining human cooperation: A sketch of the evidence. Behavioral and Brain Sciences, 1-71.

Röös, E., Sundberg, C., Tidåker, P., Strid, I., \& Hansson, P.-A. (2013). Can carbon footprint serve as an indicator of the environmental impact of meat production? Ecological Indicators, 24, 573-581. doi:https://dx.doi.org/10.1016/j.ecolind.2012.08.004 


\section{SIMON}

Sandemose, A. (1933). En flyktning krysser sitt spor: fortelling om en morders barndom (Vol. 28). Copenhagen, DK: Gyldendal.

Sennett, R. (2012). Together: The rituals, pleasures and politics of cooperation: Yale University Press.

Sentralbyrå, S. (2016). Norsk Statistisk Sentralbyrå (Statistics Norway - official statistics about Norwegian society since 1876). Retrieved from http://www.ssb.no/en

Silverstein, A., Cross, D., Brown, J., \& Rachlin, H. (1998). Prior experience and patterning in a prisoner's dilemma game. Journal of Behavioral Decision Making, 11(2), 123-138. doi:10.1002/(sici)10990771(199806)11:2<123::aid-bdm283>3.3.co;2-x

Simon, C. (2016a). Cultural Group Selection in the Light of the Selection of Extended Behavioral Patterns. Behavioral and Brain Sciences, 39. doi:10.1017/S0140525X1400106X

Simon, C. (2016b). Towards a Fully Rounded Selectionist Approach. Norsk Tidsskrift for Atferdsanalyse, 43(1), 7176.

Simon, C., \& Baum, W. M. (2012). Expelling the meme-ghost from the machine: an evolutionary explanation for the spread of cultural practices.

Simon, C., \& Baum, W. M. (2017). Allocation of Speech in Conversation. Journal of Experimental Analysis of Behavior, 107.

Skatteetaten. (2016). Søk i skattelistene. Retrieved from https://www.skatteetaten.no/no/Person/Skatteoppgjor/Sok-iskattelistene/

Skinner, B. F. (1948). 'Superstition'in the pigeon. Journal of experimental psychology, 38(2), 168. doi: $10.1037 / \mathrm{h} 0055873$

Stone, S. (Writer). (2015). The Daughter. In W. F. Screen NSW (Producer). Australia.

M. Strøksnes (Producer). (2016, 16.07.). NRK Sommar i P2 [Retrieved from https://radio.nrk.no/serie/sommer-ip2/mktr13002716/16-07-2016

The Local. (2014). One in ten Swedes is vegetarian: survey. Retrieved from http://www.thelocal.se/20140321/onein-ten-swedes-is-vegetarian-survey

Thorndike, E. L. (1911/2000). Animal intelligence: Experimental studies. New York: The Macmillan company.

Tsakumis, G. T., Curatola, A. P., \& Porcano, T. M. (2007). The relation between national cultural dimensions and tax evasion. Journal of International Accounting, Auditing and Taxation, 16(2), 131-147. doi:10.1016/j.intaccaudtax.2007.06.004

Turchin, P. (2007). War and peace and war: The rise and fall of empires: Penguin.

UN. (2015). Human Development Report New York, NY: United Nations Development Programme.

Wilson, D. S., Hayes, S., Biglan, A., \& Embry, D. (2014). Evolving the future: Toward a science of intentional change. Behavioral and Brain Sciences, 37(04), 395-416.

Wilson, D. S., Hayes, S. C., Biglan, A., \& Embry, D. D. (2014). Collaborating on evolving the future. Behavioral and Brain Sciences, 37(4), 438-460. doi:10.1017/S0140525X14000016

Wilson, D. S., \& Hessen, D. O. (2014). Blueprint for the Global Village. Cliodynamics: The Journal of Quantitative History and Cultural Evolution, 5(1). doi: 10.1017/s0140525x13001593

Wilson, D. S., Hessen, D. O., Lieberman, J., Grinde, B., Gule, L., Lieberman, G. K., . . Krall, L. (2016). The Norway Project. Retrieved from https://evolution-institute.org/wpcontent/uploads/2016/03/20160623 ei norway low-res.pdf

Wilson, D. S., Ostrom, E., \& Cox, M. E. (2013). Generalizing the core design principles for the efficacy of groups. Journal of Economic Behavior \& Organization, 90, 21-32. doi:10.1016/j.jebo.2012.12.010

Wilson, D. S., \& Sober, E. (1998). Multilevel selection and the return of group-level functionalism. Behavioral and Brain Sciences, 21(2), 305-306. doi:https://doi.org/10.1017/s0140525x98221194

Witoszek, N. (2011). The origins of the" regime of goodness": remapping the cultural history of Norway. Oslo, Norway: Universitetsforlaget.

Witoszek, N. (2014). The Beauty of "Getting to Norway": Comments on David Sloan Wilson and Dag's Hessen's essay "Blueprint for the Global Village". Cliodynamics: The Journal of Quantitative History and Cultural Evolution, 5(1), 132-136.

Witoszek, N., \& Hanssen, T. (1998). Norske naturmytologier: Fra Edda til фkofilosofi. Oslo, Norway: Pax Forlag $\mathrm{A} / \mathrm{S}$.

Worum, H. (2015). Psykisk helse og friluftsliv: en kvalitativ studie med fokus på deltakernes erfaringer med turgrupper ifriluft, og dets betydning for den psykiske helse. (Master's Thesis), Norwegian University of Life Sciences, Ås. 